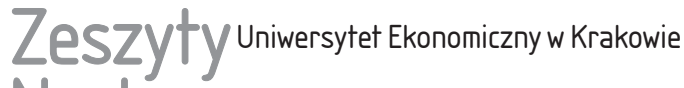 Naukowe
}

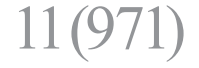

ISSN 1898-6447

Zesz. Nauk. UEK, 2017: 11 (971): 5-25 DOI: 10.15678/ZNUEK.2017.0971.1101

Grażyna Dehnel

\section{Dobór modelu a obciążenie szacunku na przykładzie estymatora GREG w badaniu małych przedsiębiorstw}

\section{Streszczenie}

Estymacja dotycząca populacji charakteryzujących się silną asymetrią i obecnością obserwacji odstających jest zagadnieniem trudnym, zwłaszcza gdy prowadzona jest na niskim poziomie agregacji. Zastosowanie klasycznych, bezpośrednich metod estymacji nie pozwala na otrzymanie wiarygodnych szacunków. Potrzeba uzyskania szczegółowych informacji oraz szerszych możliwości wykorzystania danych pochodzących z rejestrów administracyjnych skłania do poszukiwania innych, nieklasycznych metod szacunku. Przykładem może być estymacja typu GREG. W artykule podjęto próbę zbadania wpływu wyboru modelu uwzględnionego w ramach estymatora GREG na jakość szacunku parametru populacji przedsiębiorstw. Analizę przeprowadzono na podstawie danych pochodzących z badania małych przedsiębiorstw. Badaną zmienną był przeciętny przychód przedsiębiorstwa. Jako zmienne pomocnicze wykorzystano zmienne opóźnione pochodzące z rejestrów administracyjnych. Badanie prowadzono w przekroju województw z uwzględnieniem rodzaju prowadzonej działalności gospodarczej.

Słowa kluczowe: estymacja GREG, statystyka gospodarcza, estymacja typu model-assisted, obserwacje odstające.

Klasyfikacja JEL: C40, C51.

Grażyna Dehnel, Uniwersytet Ekonomiczny w Poznaniu, Wydział Informatyki i Gospodarki Elektronicznej, Katedra Statystyki, al. Niepodległości 10, 61-875 Poznań, e-mail: g.dehnel@ue. poznan.pl 


\section{Wprowadzenie}

Rosnące potrzeby informacyjne w zakresie statystyki gospodarczej powodują konieczność prowadzenia badań w kierunku wzbogacenia i rozszerzania zakresu dostarczanych danych dotyczących przedsiębiorczości. Zadanie to jest o tyle trudne, że badaniom prowadzonym na podstawie populacji przedsiębiorstw towarzyszy zwiększający się z roku na rok odsetek braków odpowiedzi. Dodatkowo zakres zmian w systemie statystyki gospodarczej, które brane są pod uwagę, jest ograniczony przez takie czynniki, jak koszty badania oraz obciążenie respondentów wynikające ze sprawozdawczości statystycznej. Zaspokojenie potrzeby uzyskania informacji wymusza zatem poszukiwanie metod szacunku zmierzających do zwiększenia stopnia wykorzystania źródeł administracyjnych. Adaptacja nowych rozwiązań ma przyczynić się do poprawy efektywności prowadzonych szacunków, a przede wszystkim do zwiększenia liczby przekrojów, w których publikowane są dane. Próby adaptacji nieklasycznych metod estymacji w odniesieniu do podmiotów gospodarczych zostały podjęte m.in. w pracach: [Chambers i in. 2014, Clark, Kokic i Smith 2017, Dehnel 2014, 2016]. Szukając nowych podejść do estymacji parametrów dotyczących przedsiębiorstw, należy uwzględnić specyfikę badanej populacji. Populacja przedsiębiorstw charakteryzuje się m.in. obecnością obserwacji odstających. Mając to na względzie, w niniejszym artykule poddano analizie metodę szacunku stosowaną w ramach statystyki małych obszarów zaliczaną do grupy model-assisted. Celem badania była ocena wpływu doboru modelu uwzględnionego w ramach estymatora typu GREG na jakość szacunku przeciętnego przychodu małych przedsiębiorstw. W estymacji zaproponowano wykorzystanie opóźnionych zmiennych pomocniczych pochodzących z zasobów administracyjnych. Oceny estymatorów dokonano na podstawie badania empirycznego, w którym wykorzystano dane dotyczące małych przedsiębiorstw działających w ramach sekcji: przemysł, budownictwo, handel i transport.

\section{Metoda estymacji}

W badaniach prowadzonych w zakresie statystyki przedsiębiorstw opartych na podejściu modelowym często zdarza się, że warunek dotyczący homoskedastyczności nie jest zachowany. Prowadzi to do nieefektywnych ocen parametrów regresji. Stąd też poszukuje się metod, które pozwolą na złagodzenie naruszenia założeń liniowego modelu regresji. Przykładem może być modyfikacja estymatora GREG zaproponowana w pracy R. Chambersa, H. Falveya, D. Hedlina i P. Kokica [2001], zwana dalej modelem Chambersa. 
W modelu Chambersa proponuje się włączenie do modelu dodatkowej zmiennej pomocniczej $z_{i}^{r}$. W ramach klasycznej postaci estymatora GREG wartości globalnej zmiennej $Y$ [Lehtonen, Särndal i Veijanen 2016]

$$
\hat{Y}_{G R E G, d}=\sum_{i \in U_{d}} \hat{y}_{i}+\sum_{i \in s_{d}} w_{i} e_{i},
$$

gdzie $\hat{y}_{i}=\mathbf{x}_{i}^{\prime} \hat{\boldsymbol{\beta}}_{d}$, wektor parametrów modelu $\hat{\boldsymbol{\beta}}_{d}$ szacowany jest na podstawie zmodyfikowanego wzoru uwzględniającego dodatkową zmienną $z$ [Chambers $i$ in. 2001]:

gdzie:

$$
\hat{\boldsymbol{\beta}}_{d}=\left(\sum_{i \in s_{d}} \frac{w_{i} \mathbf{x}_{i} \mathbf{x}_{i}^{\prime}}{z_{i}^{\gamma}}\right)^{-1}\left(\sum_{i \in s_{d}} \frac{w_{i} \mathbf{x}_{i} y_{i}}{z_{i}^{\gamma}}\right),
$$

$w_{i}$ - wagi wynikające ze schematu losowania,

$\mathbf{x}$ - wektor zmiennych pomocniczych, w zależności od podejścia - liczba osób pracujących lub przychód,

$z_{i}^{\gamma}$ - zmienna pomocnicza w modelu regresji $y$ względem $x$ zakładającym heteroskedastyczność, w zależności od podejścia - liczba osób pracujących lub przychód,

$\gamma$ - parametr określający stopień heteroskedastyczności,

$U_{d}$ - część populacji generalnej o elementach należących do domeny $d$,

$s_{d}$ - część próby wylosowanej z populacji o elementach należących do domeny $d$.

Estymator modelu Chambersa wyrażony za pomocą wzoru (1) można przedstawić w postaci, która jest tożsama $\mathrm{z}$ formułą klasycznego estymatora GREG:

$$
\hat{Y}_{G R E G, d}=\sum_{i \in s_{d}} w_{i} g_{i} y_{i} .
$$

Różnica dotyczy jedynie definicji wagi $g_{i}$ zależnej od wartości cechy dodatkowej $x$ u jednostek wylosowanych do próby, zdefiniowanej jako:

gdzie:

$$
g_{i}=1+\left(X_{d}-\hat{X}_{H T, d}\right)^{\prime}\left(\sum_{i \in s_{d}} \frac{w_{i} \mathbf{x}_{i} \mathbf{x}_{i}^{\prime}}{z_{i}^{\gamma}}\right)^{-1}\left(\frac{\mathbf{x}_{i}}{z_{i}^{\gamma}}\right),
$$

$d$-domena,

$g_{i}$ - wagi zależne od wartości cechy dodatkowej u $i$-tej jednostki wylosowanej do próby,

$\hat{Y}_{G R E G, d}$ - ocena wartości globalnej w domenie $d$ na podstawie estymatora GREG,

$\hat{X}_{H T, d}$ - estymator bezpośredni Horvitza-Thompsona wartości globalnej zmiennej pomocniczej $x$ w domenie $d$,

$X$ - wartość globalna zmiennej pomocniczej $x$,

$\gamma$-parametr określający stopień heteroskedastyczności, dla $\gamma=0$ estymator modelu Chambersa przyjmuje klasyczną postać estymatora GREG. 
Na podstawie wcześniej prowadzonych badań statystycznych wiadomo, że wartość parametru $\gamma$ zawiera się w przedziale $\langle 1,2\rangle$ [Särndal, Swensson i Wretman 1992], stąd też w przeprowadzonym badaniu przeanalizowano trzy podejścia (dla $\gamma$ równego odpowiednio $1,1,5$ i 2) reprezentujące estymatory $\hat{Y}_{G R E G}^{1}, \hat{Y}_{G R E G}^{1,5}, \hat{Y}_{G R E G}^{2}$. $\mathrm{W}$ estymatorach tych $\mathrm{w}$ liniowym modelu regresji dopuszcza się niezachowanie warunku homoskedastyczności, przy czym poziom heteroskedastyczności określany jest przez parametr $\gamma$.

\section{Założenia badania}

Badaniem empirycznym objęto małe przedsiębiorstwa (10-49 pracujących) prowadzące działalność gospodarczą w ramach sekcji: przemysł, budownictwo, handel i transport. Analizie poddano model, w którym zmienną zależną stanowił przychód uzyskany przez przedsiębiorstwa w czerwcu 2012 r. Za zmienne niezależne przyjęto przychód, koszt oraz liczbę pracujących według stanu zanotowanego w grudniu 2011 r. Decyzję o wykorzystaniu zmiennych opóźnionych podjęto, biorąc pod uwagę ograniczenia czasowe, z jakimi musi się liczyć GUS, prowadząc badania statystyczne. Chodzi przede wszystkim o opóźnienie, jakie ma miejsce przy przekazywaniu statystyce publicznej zasobów administracyjnych [Wykorzystanie danych... 2016].

Dane dotyczące zmiennej zależnej pochodziły z badania DG-1 [Dehnel 2014]. Z kolei źródłem informacji o zmiennych niezależnych były rejestry administracyjne. Szacunku dokonano w przekroju regionalnym, z uwzględnieniem rodzaju prowadzonej działalności gospodarczej. Przekrój regionalny obejmował jednostki na poziomie województw, zaś rodzajowi prowadzonej działalności odpowiadały sekcje PKD.

W ocenie jakości estymacji za punkt odniesienia przyjęto oszacowania otrzymane na podstawie estymatorów bezpośrednich - Horvitza-Thompsona (HT) i typu GREG, włączając w to jego postać ilorazową (oznaczoną w artykule jako RAT).

Estymator HT

gdzie:

$$
\hat{Y}_{H T, d}=\frac{N_{d}}{n_{d}} \sum_{i \in s_{d}} y_{i}
$$

$\hat{Y}_{H T, d}$ - estymator bezpośredni HT wartości globalnej zmiennej $y \mathrm{w}$ domenie $d$, $N_{d}$ - liczebność populacji generalnej w domenie $d$,

$n_{d}$ - liczebność próby w domenie $d$,

$y_{i}$ - wartość zmiennej badanej u $i$-tej jednostki. 
Estymator GREG

$$
\hat{Y}_{G R E G, d}^{0}=\hat{Y}_{G R E G, d}=\sum_{i \in U_{d}} \hat{y}_{i}+\sum_{i \in s_{d}} w_{i} e_{i},
$$

gdzie $\hat{y}_{i}=\mathbf{x}_{i}^{\prime} \hat{\boldsymbol{\beta}}_{d}$, wektor parametrów modelu $\hat{\boldsymbol{\beta}}_{d}$ szacowany jest na podstawie wzoru [Rao, Molina 2015]:

$$
\hat{\boldsymbol{\beta}}_{d}=\left(\sum_{i \in s_{d}} w_{i} \mathbf{x}_{i} \mathbf{x}_{i}^{\prime}\right)^{-1}\left(\sum_{i \in s_{d}} w_{i} \mathbf{x}_{i} y_{i}\right) .
$$

Estymator $\hat{Y}_{G R E G}^{0}$ przyjmuje postać estymatora typu GREG, jednak jego wartości różnią się od szacunków otrzymanych na podstawie klasycznego podejścia GREG. Różnice wynikają z tego, że w przypadku estymatora modelu Chambersa $\hat{Y}_{G R E G}^{0}$ W szacunku nie są uwzględniane wszystkie jednostki wylosowane do próby z domeny $d$. Pomijane są bowiem te, dla których zmienna pomocnicza ' $z$ ' przyjmie wartość zero.

Jako zmienne pomocnicze typu ' $x$ ' i ' $z$ ' wykorzystano liczbę osób pracujących (dane pochodzące z ZUS) oraz przychody (dane pochodzące z rejestru podatkowego). W modelu Chambersa zakłada się, że każda ze zmiennych pomocniczych może być wykorzystana zarówno jako zmienna ' $x$ ', jak i ' $z$ ' (z zastrzeżeniem, że zmienną ' $z$ ' nie może być taka zmienna, która przyjmuje wartości zerowe). W związku z powyższym ostatecznie głębszej analizie poddano podejście, w którym za zmienną ' $z$ ' przyjęto liczbę osób pracujących.

\section{Metoda oceny precyzji}

Do oceny precyzji i dokładności otrzymanych szacunków wykorzystano metodę bootstrapową. Wykonano 1000 repetycji losowania podprób, na podstawie których oszacowano wartość przychodu przedsiębiorstw dla czerwca $2012 \mathrm{r}$. w przekroju przyjętych domen studiów. Efektywność estymacji oceniono na podstawie współczynnika zmienności estymatora [Bracha 2004]:

$$
C V\left(\hat{Y}_{d}\right)=\frac{\sqrt{\operatorname{Var}\left(\hat{Y}_{d}\right)}}{E\left(\hat{Y}_{d}\right)}=\frac{\sqrt{\frac{1}{999} \sum_{b=1}^{1000}\left(\hat{Y}_{b, d}-\hat{Y}_{d}\right)}}{E\left(\hat{Y}_{d}\right)} .
$$

Wskaźnik ten określa udział błędu estymacji w wartości szacowanej zmiennej na poziomie domeny. W badaniach prowadzonych przez GUS oraz badaniach empirycznych przyjmuje się, że wyniki szacunków mogą być uznane za wiarygodne, jeżeli wartość $C V$ nie przekracza $10 \%$. Jeśli przyjmuje on wartości z przedziału 10-20\%, szacunki należy interpretować ostrożnie. Jeżeli natomiast poziom $C V$ jest wyższy od $20 \%$, oceny estymatorów nie są uznawane za wiarygodne [Ludność... 2013]. 


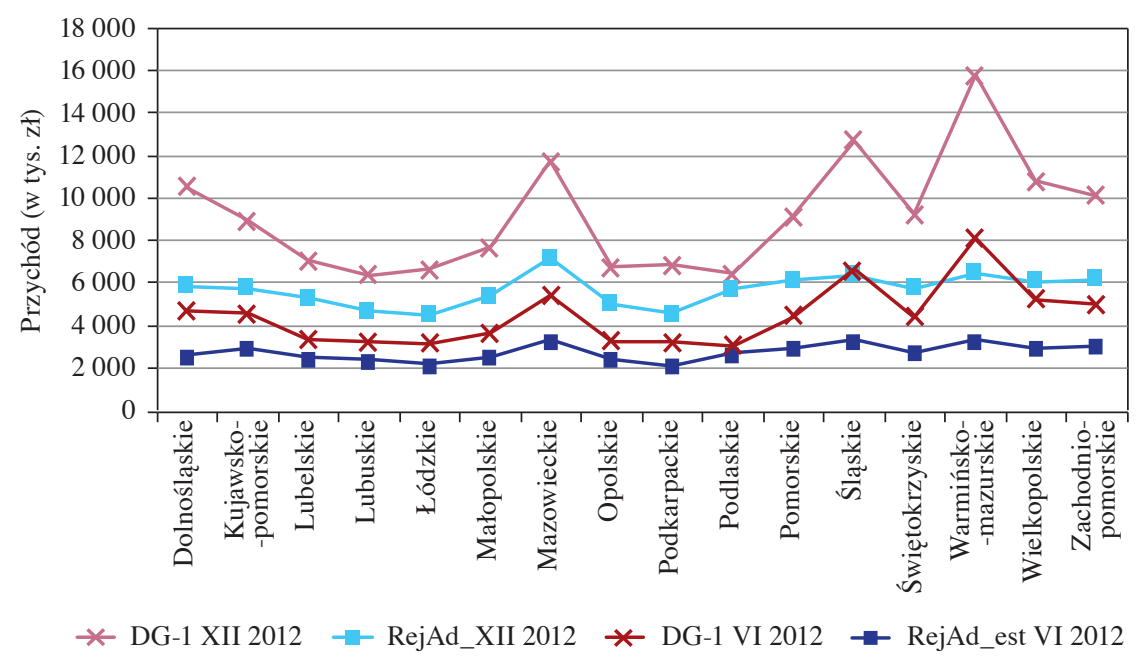

Rys. 1. Wartości przychodu przedsiębiorstw w czerwcu i grudniu 2012 r. zarejestrowane na podstawie badania DG-1 oraz zeznań podatkowych w sekcji ,przemysł”

Źródło: opracowanie własne na podstawie danych pochodzących z badania DG-1 oraz rejestrów administracyjnych.

Ocena obciążenia wymaga znajomości wartości szacowanego parametru w populacji generalnej. Ze względu na brak dostępu w badaniu do informacji o tej wielkości oszacowano ją w sposób pośredni, na podstawie danych pochodzących z zeznań podatkowych z grudnia 2012 r. Przyjęto, że relacja przychodu zarejestrowanego w zeznaniach podatkowych dla badanych przedsiębiorstw na poziomie domeny studiów do przychodu określonego na podstawie badania DG-1 jest stała. W celu graficznej prezentacji zależności między wielkościami wykorzystano dane dotyczące sekcji „przemysł” (por. rys. 1). W pozostałych sekcjach PKD relacja między zmiennymi przedstawia się podobnie.

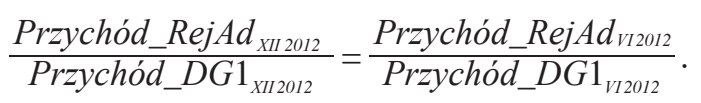

Takie podejście pozwoliło na wyznaczenie przybliżonej wartości przychodu przedsiębiorstw dla czerwca $2012 \mathrm{r}$. 


\section{Wyniki szacunków i ocena ich jakości*}

Analizę rozpoczęto od oceny rozkładów przedsiębiorstw według badanych zmiennych. Wartości współczynnika zmienności wahały się w granicach 47-649\%. Zanotowano również silną asymetrię, współczynnik asymetrii przyjmował wartości w przedziale $0,6-17,1$. Biorąc pod uwagę własności rozkładów podmiotów gospodarczych, za pomocą testów White'a oraz Breuscha-Pagana weryfikacji poddano hipotezę zakładającą homoskedastyczność. Wyniki testów w przypadku zdecydowanej większości wyróżnionych domen potwierdziły słuszność tezy o zmienności składnika losowego (por. tabela 1). To z kolei uzasadniało wykorzystanie opisanych wyżej estymatorów GREG uwzględniających dodatkową cechę ' $z$ '.

Ocenie poddano zarówno efektywność, jak i dokładność estymacji. W ocenie precyzji estymacji za punkt odniesienia przyjęto szacunek otrzymany za pomocą klasycznych, bezpośrednich estymatorów HT oraz typu GREG, włączając w to jego postać ilorazową. Biorąc pod uwagę wartości miary efektywności $C V$, można zauważyć, że największym zróżnicowaniem charakteryzuje się estymator HT (por. rys. 2-5 i tabela 2). Mniejszą zmienność obserwujemy w przypadku klasycznych estymatorów GREG, w których wykorzystuje się zmienne pomocnicze pochodzące z rejestrów administracyjnych. Analizując wyniki można zauważyć, że precyzja szacunku estymacji typu GREG zależy od liczebności próby. Jest ona $\mathrm{z}$ reguły wyższa w sekcjach liczniej reprezentowanych w próbie, takich jak handel i przemysł. W większości wyróżnionych domen współczynniki zmienności estymatorów modelu Chambersa kształtują się na podobnym poziomie. Wyjątek stanowi sekcja „transport”, w której liczebność próby jest najmniejsza i wynosi w niektórych domenach 5 jednostek.

W ocenie dokładności szacunku przychodu przedsiębiorstw wykorzystano wartości referencyjne wyznaczone na podstawie zależności ilorazowej opisanej powyżej (por. wzór (9)). Dodatkowo, w celu pełniejszej oceny, model Chambersa porównano z estymacją HT oraz GREG (por. rys. 6-9, tabela 3). Otrzymane wyniki wskazują, że zastosowanie modelu Chambersa w znacznym stopniu poprawiło dokładność szacunku w przypadku estymacji HT i GREG. Zastosowanie estymacji HT w prawie wszystkich badanych domenach doprowadziło do znacznego przeszacowania wartości przychodu. Z kolei w przypadku wszystkich estymatorów typu GREG widoczne jest niedoszacowanie badanego parametru, jednak wielkość odchylenia od wartości referencyjnej jest zdecydowanie mniejsza niż w przypadku estymatora HT. Zastosowanie estymatora GREG, a w szczególności jego zmodyfikowanej wersji, przyniosło największą poprawę dokładności szacunku dla domen, dla których zanotowano największą dyspersję zmiennych uwzględnionych w modelu.

* Wybrane wyniki badań zostały opublikowane w pracy [Dehnel 2017]. 


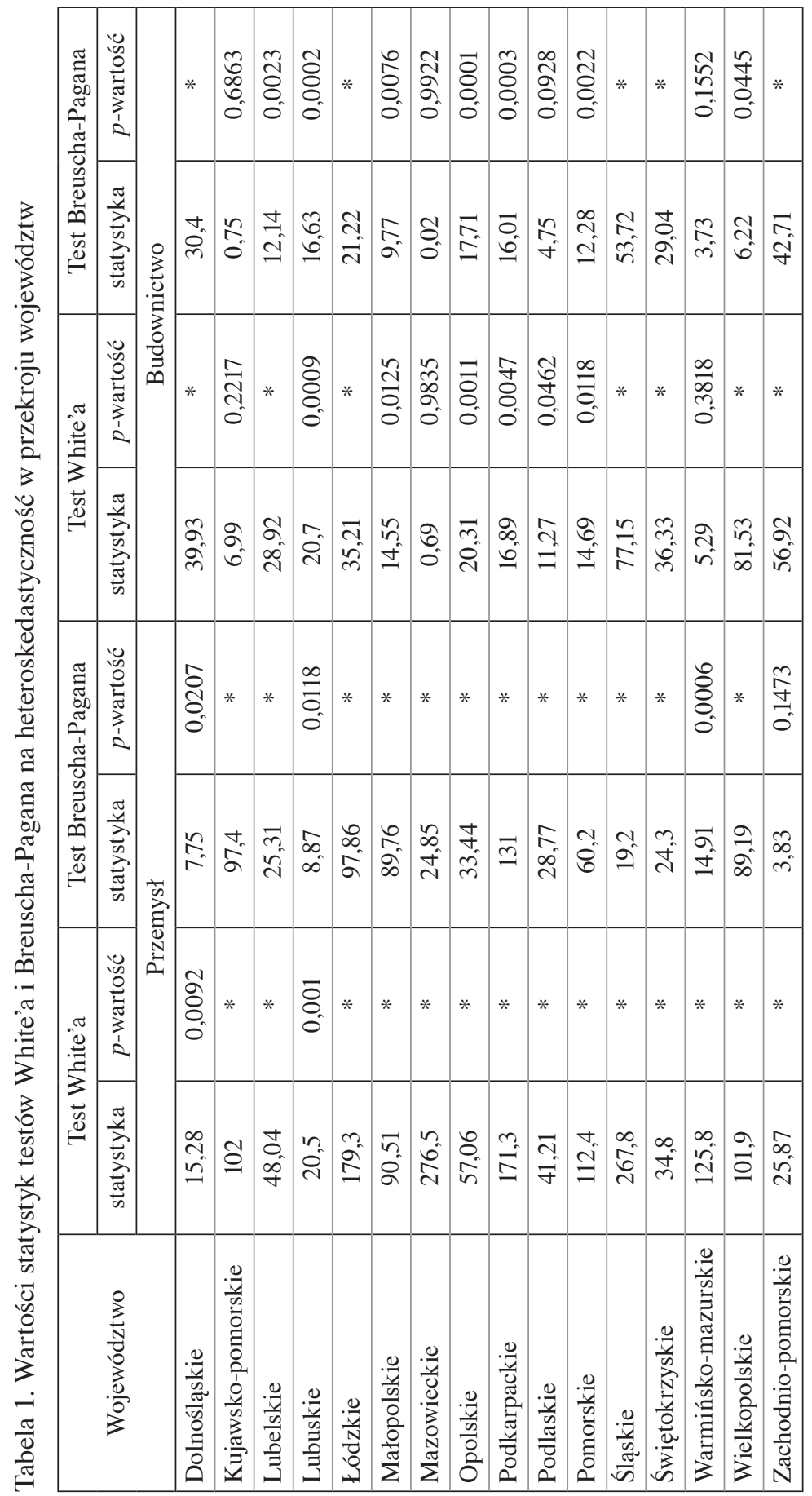




\begin{tabular}{|c|c|c|c|c|c|c|c|c|c|c|c|c|c|c|c|c|}
\hline 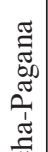 & $\left|\begin{array}{l}0 \\
0 \\
0 \\
0 \\
0 \\
3 \\
1 \\
1 \\
2\end{array}\right|$ & $\mid \frac{0}{8}$ & 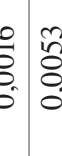 & $\begin{array}{l}\stackrel{m}{8} \\
\dot{B} \\
\dot{b}\end{array}$ & 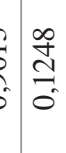 & 范 & $\begin{array}{l}0 \\
8 \\
8 \\
0 \\
0\end{array}$ & 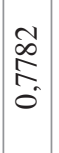 & $\begin{array}{c}q \\
c \\
0 \\
0 \\
0\end{array}$ & 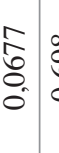 & & $\begin{array}{c}0 \\
\delta_{0}^{2} \\
\delta_{0}^{-}\end{array}$ & $\mid \frac{8}{\partial}$ & 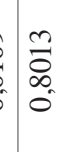 & & ळ̂̊ \\
\hline 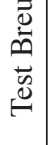 & 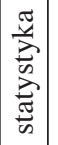 & $=$ & ç & 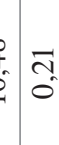 & 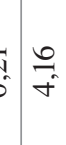 & $\stackrel{8}{8}$ & \begin{tabular}{|l}
$\bar{m}$ \\
$\tilde{n}$
\end{tabular} & $n$ & $\begin{array}{l}\infty \\
\stackrel{-}{-} \\
-\end{array}$ & $\begin{array}{c}\text { ले } \\
\text { जi }\end{array}$ & $\begin{array}{l}\mathbb{3} \\
0\end{array}$ & & 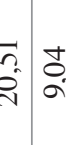 & $\underset{0}{J}$ & & \\
\hline & 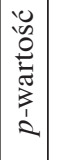 & 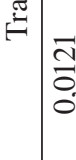 & 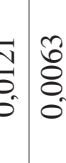 & 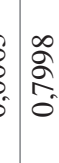 & $\hat{o}_{0}^{0}$ & $\hat{n}$ & 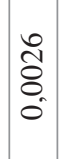 & $\begin{array}{c}\mathscr{N} \\
\infty \\
\infty \\
0\end{array}$ & $\begin{array}{l}\bar{\lambda} \\
\bar{S} \\
0 \\
0\end{array}$ & 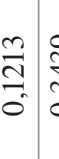 & 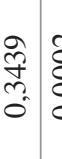 & 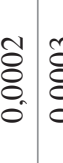 & \begin{tabular}{c|c}
$\tilde{\delta}$ & 8 \\
8 & 8 \\
8 & 8 \\
\end{tabular} & 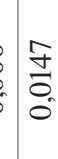 & & \\
\hline & 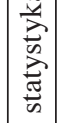 & & 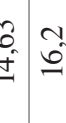 & 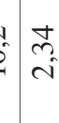 & $\stackrel{\infty}{\infty}$ & $\stackrel{\infty}{\stackrel{\Xi}{=}}$ & $\begin{array}{l}\hat{y} \\
\stackrel{\infty}{\infty}\end{array}$ & $\vec{i}$ & $\frac{\infty}{\mathfrak{m}^{2}}$ & $\underset{\infty}{\vec{\infty}}$ & 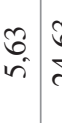 & \begin{tabular}{l|l}
$\hat{b}$ & $\alpha$ \\
$\dot{j}$ & $\alpha$
\end{tabular} & $\begin{array}{c}\infty \\
\vec{r} \\
\vec{r}\end{array}$ & 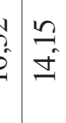 & $\begin{array}{l}5 \\
\dot{\sigma} \\
\dot{f}\end{array}$ & \\
\hline
\end{tabular}

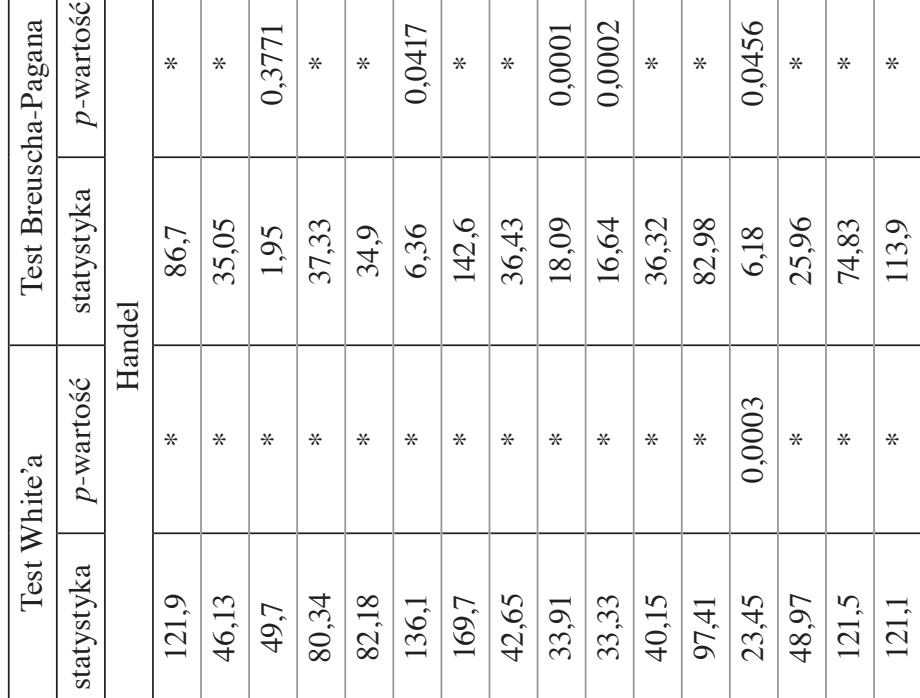

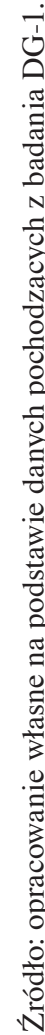




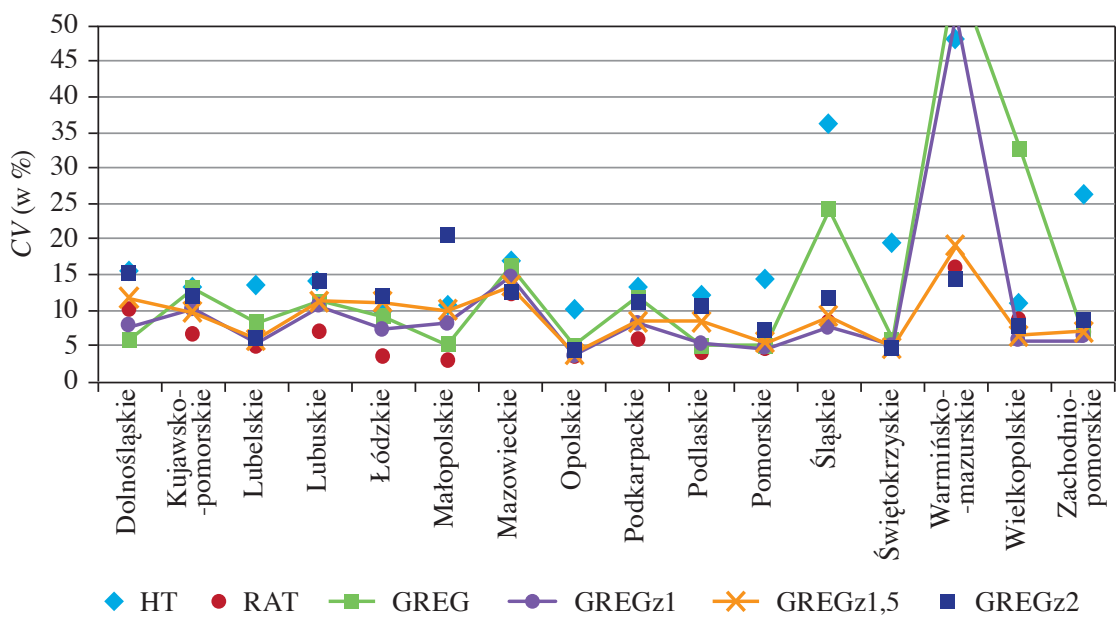

Rys. 2. Precyzja szacunku $C V$ w przekroju województw - przemysł

Źródło: opracowanie własne na podstawie danych pochodzących z badania DG-1 oraz rejestrów administracyjnych.

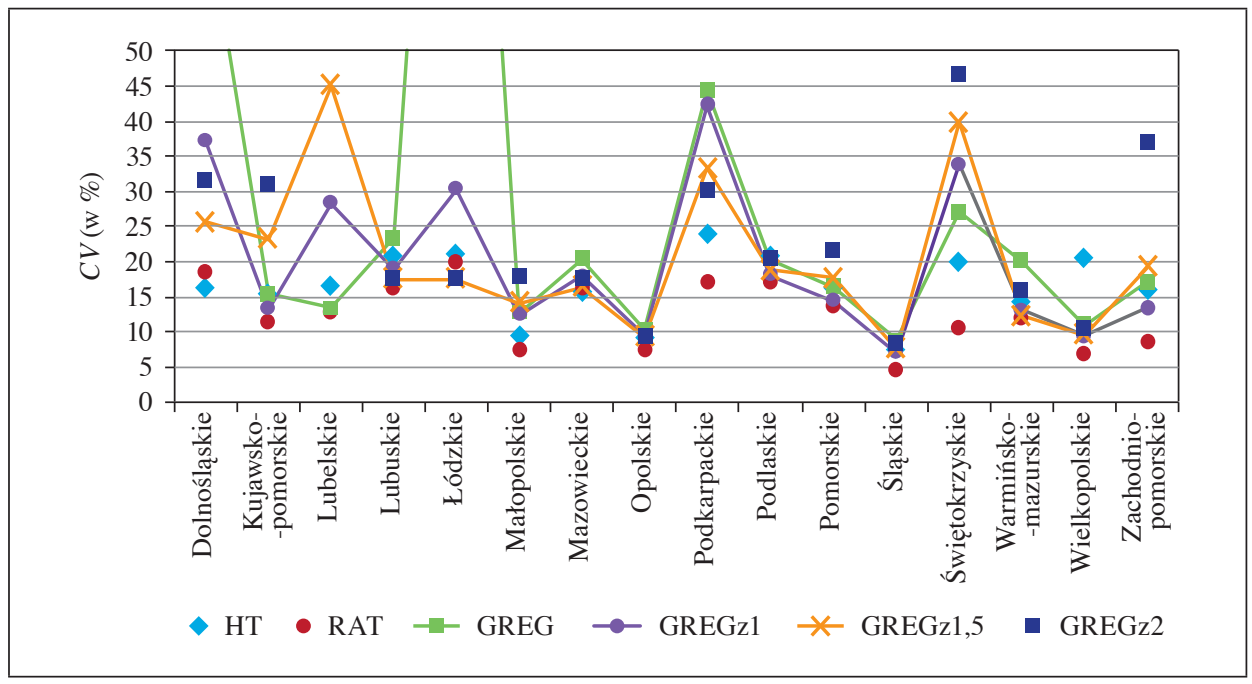

Rys. 3. Precyzja szacunku $C V$ w przekroju województw - budownictwo

Źródło: opracowanie własne na podstawie danych pochodzących z badania DG-1 oraz rejestrów administracyjnych. 


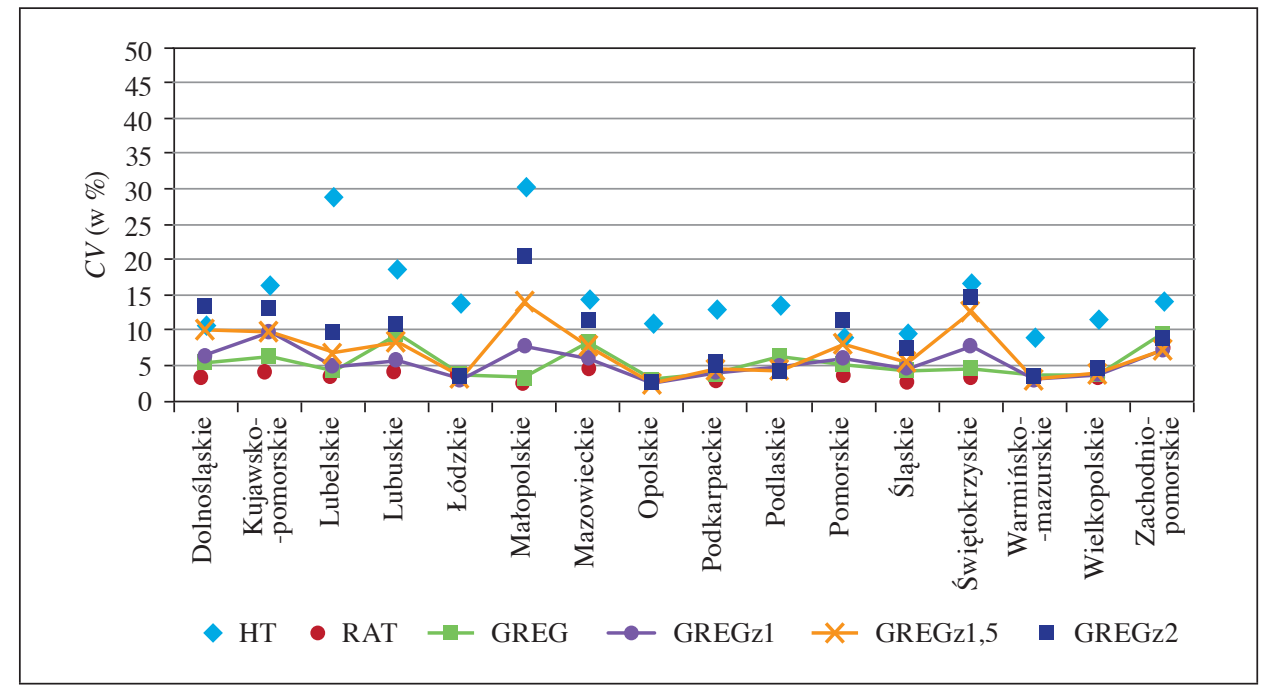

Rys. 4. Precyzja szacunku $C V$ w przekroju województw - handel

Źródło: opracowanie własne na podstawie danych pochodzących z badania DG-1 oraz rejestrów administracyjnych.

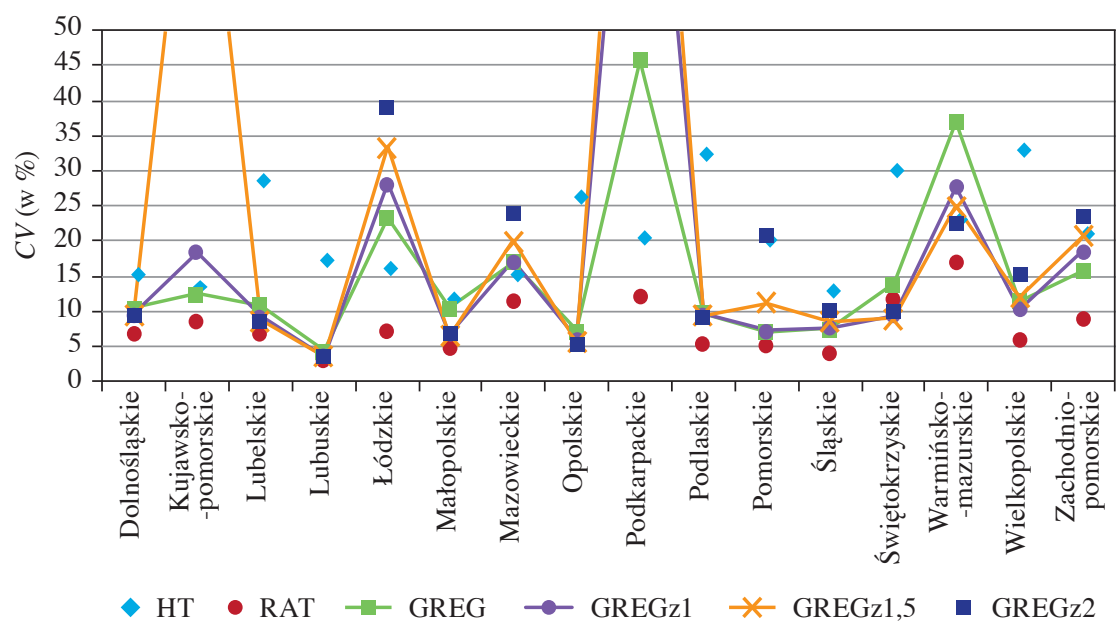

Rys. 5. Precyzja szacunku $C V$ w przekroju województw - transport

Źródło: opracowanie własne na podstawie danych pochodzących z badania DG-1 oraz rejestrów administracyjnych. 


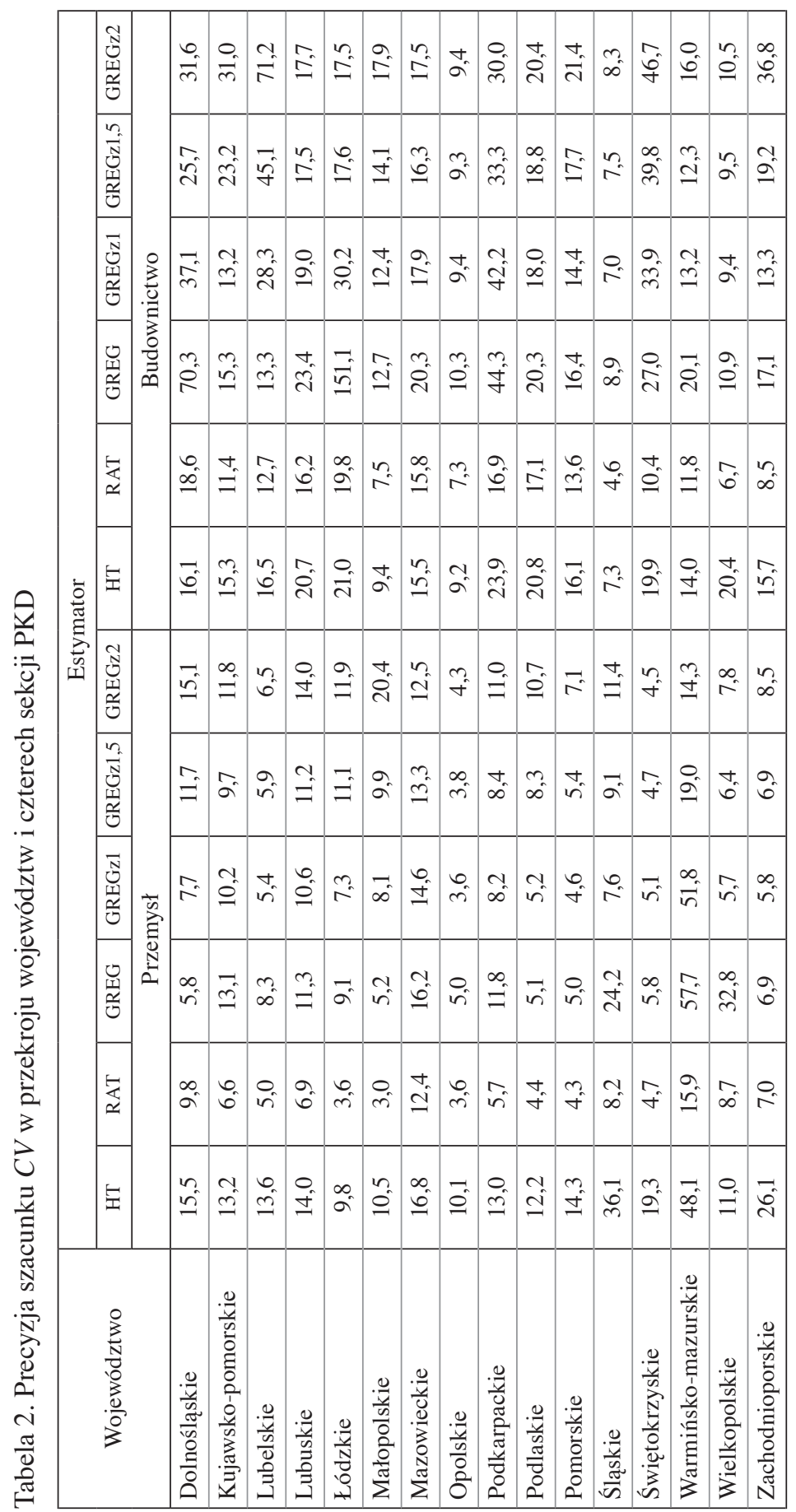




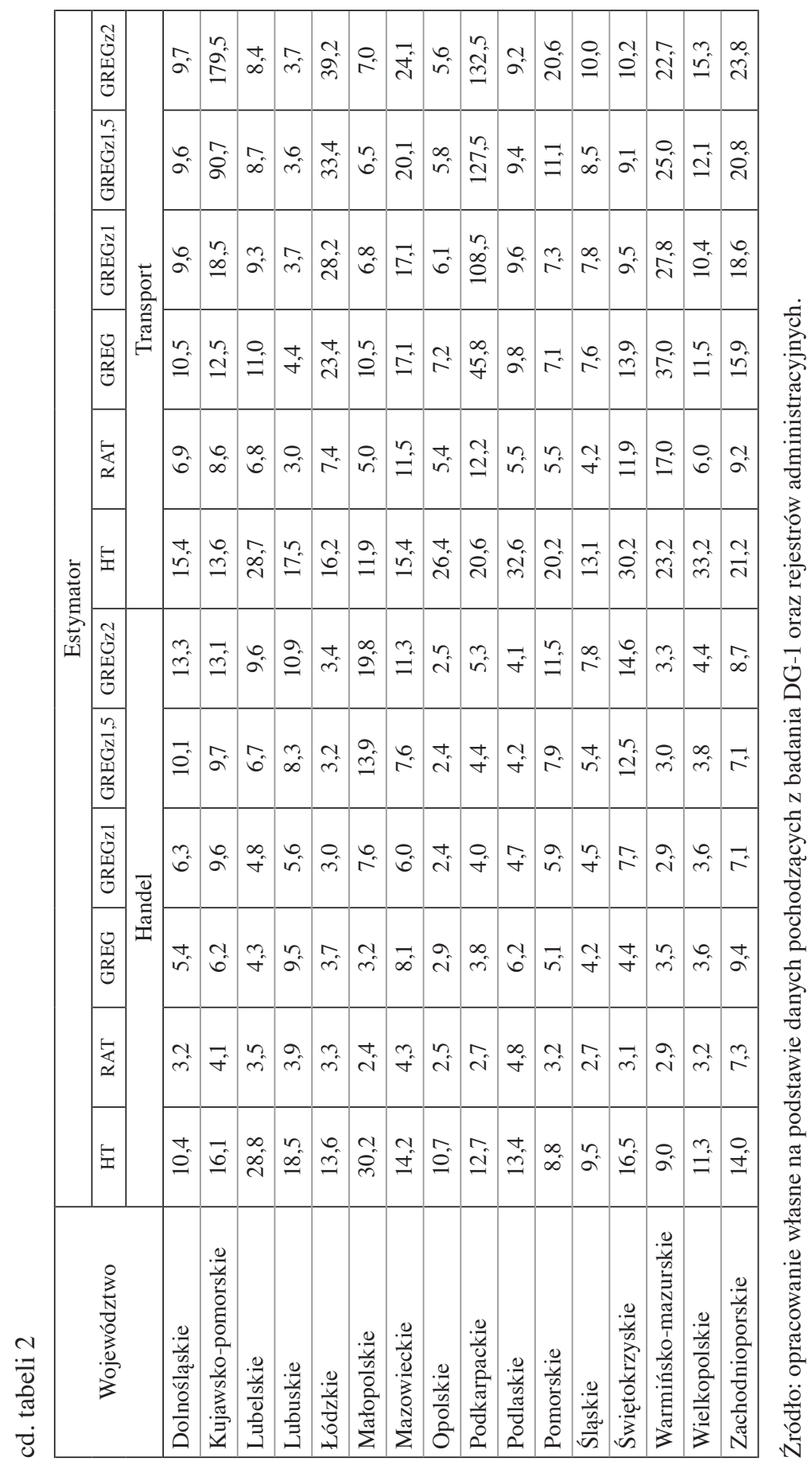




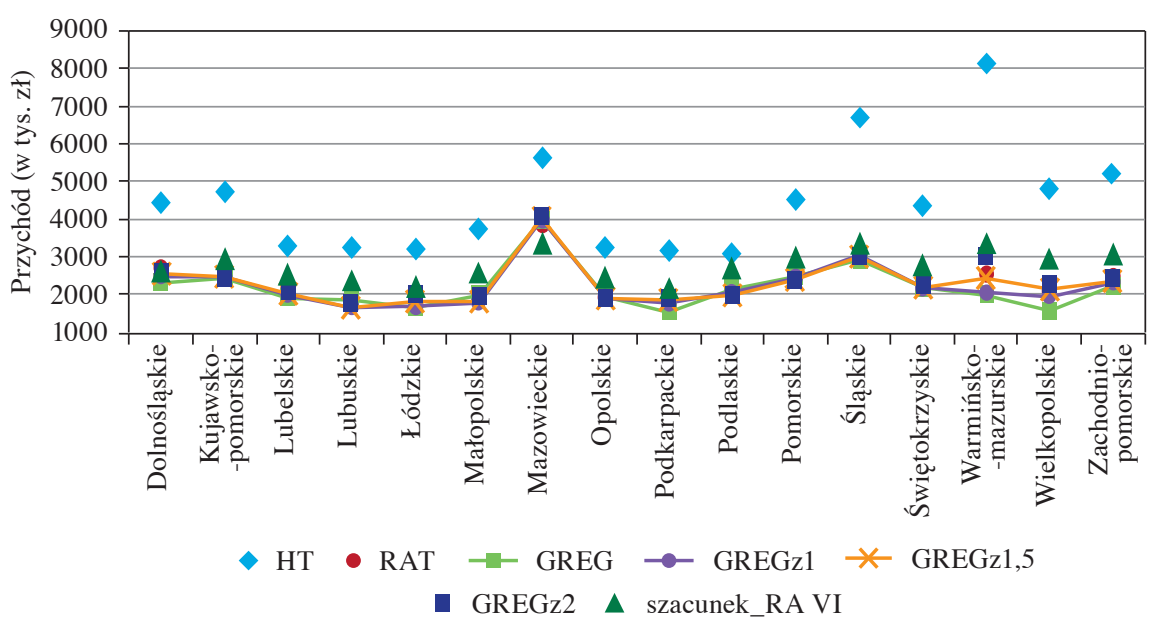

Rys. 6. Szacunek przychodu przedsiębiorstw dla czerwca 2012 r. w przekroju województw - przemysł

Źródło: opracowanie własne na podstawie danych pochodzących z badania DG-1 oraz rejestrów administracyjnych.

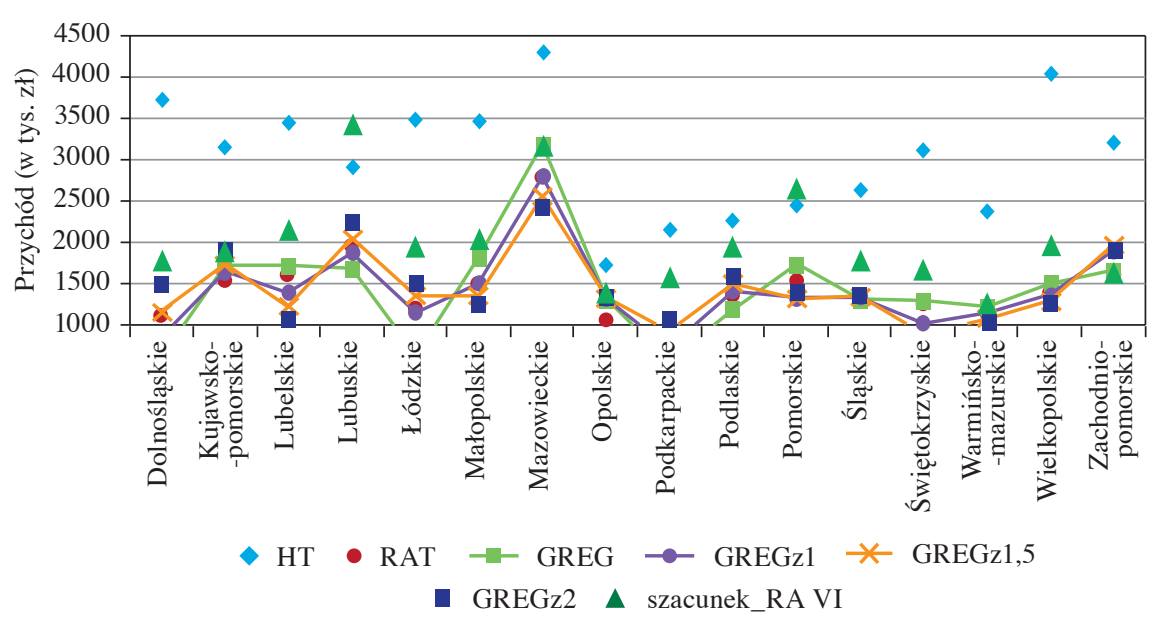

Rys. 7. Szacunek przychodu przedsiębiorstw dla czerwca 2012 r. w przekroju województw - budownictwo

Źródło: opracowanie własne na podstawie danych pochodzących z badania DG-1 oraz rejestrów administracyjnych. 


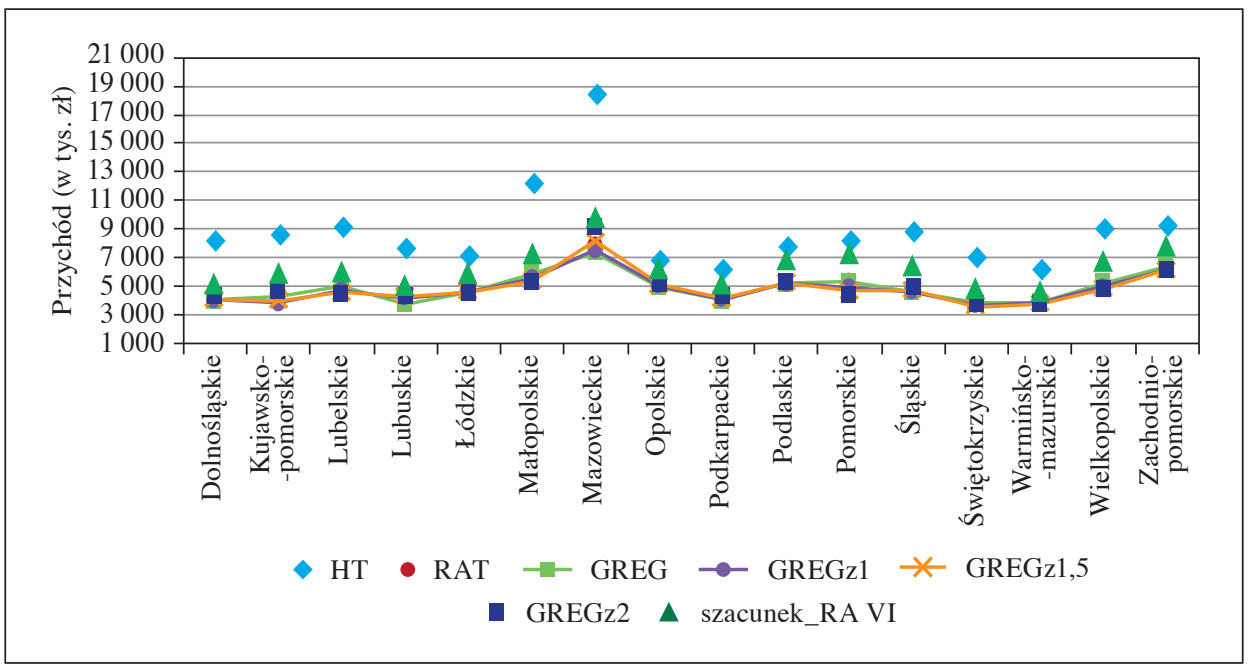

Rys. 8. Szacunek przychodu przedsiębiorstw dla czerwca 2012 r. w przekroju województw - handel

Źródło: opracowanie własne na podstawie danych pochodzących z badania DG-1 oraz rejestrów administracyjnych.

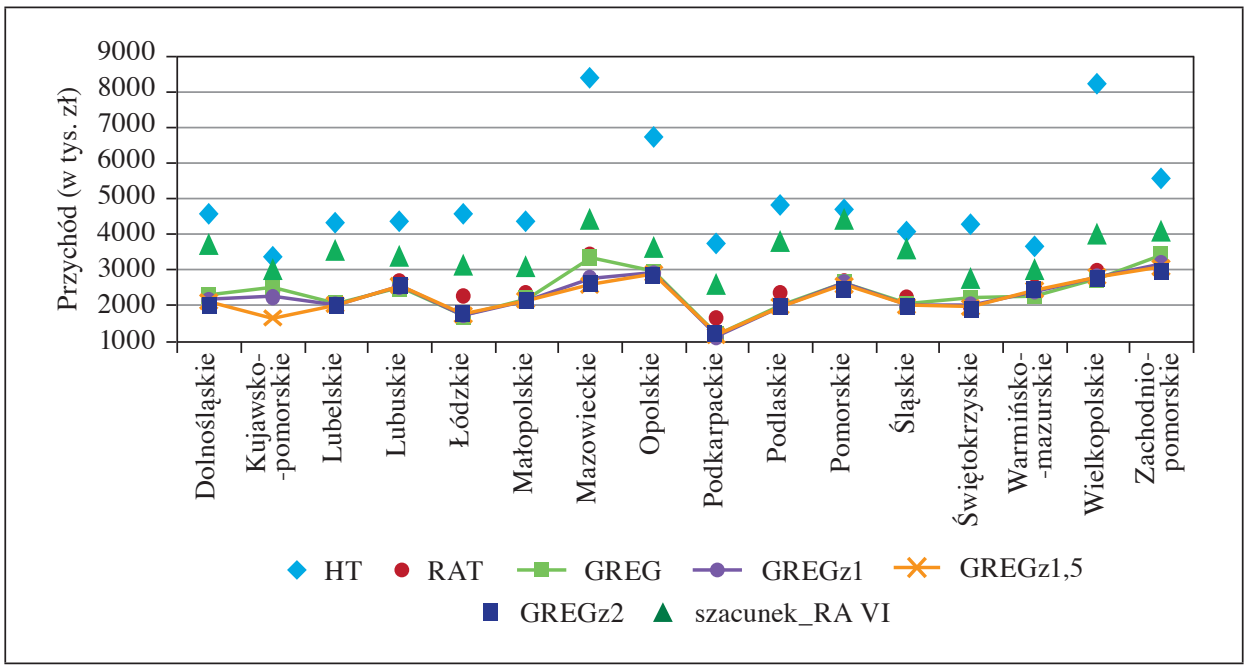

Rys. 9. Szacunek przychodu przedsiębiorstw dla czerwca 2012 r. w przekroju województw - transport

Źródło: opracowanie własne na podstawie danych pochodzących z badania DG-1 oraz rejestrów administracyjnych. 


\begin{tabular}{|c|c|c|c|c|c|c|c|c|c|c|c|c|c|c|c|c|c|c|}
\hline & $\begin{array}{l}\text { N } \\
\text { I } \\
\text { 忢 } \\
\end{array}$ & & $\mid \begin{array}{l}0 \\
\tilde{n} \\
n\end{array}$ & $\begin{array}{l}\bar{D} \\
\stackrel{\sim}{N}\end{array}$ & $\stackrel{\infty}{\Omega}$ & $\frac{m}{\hat{n}}$ & n & $\stackrel{\text { 巳 }}{\Xi}$ & ते & \begin{tabular}{l}
$\infty$ \\
$\infty$ \\
\hdashline
\end{tabular} & O্ & 导 & $\underset{\Xi}{\stackrel{\infty}{ \pm}}$ & $\begin{array}{l}\infty \\
\stackrel{0}{+} \\
\end{array}$ & $\frac{n}{1}$ & $\bar{\Xi}$ & స్ & $\stackrel{\hat{\imath}}{\underline{6}}$ \\
\hline & \begin{tabular}{|l|}
$n$ \\
$\mathbb{N}$ \\
0 \\
In \\
0 \\
0 \\
\end{tabular} & & 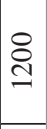 & $\frac{\tilde{n}}{\pi}$ & 守 & 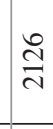 & $\stackrel{+}{ \pm}$ & ঐे & $\overline{\vec{n}}$ & $\vec{\infty}$ & $\stackrel{ \pm}{=}$ & 寽 & $\stackrel{m}{\cong}$ & 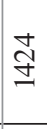 & হ & 6. & $\stackrel{N}{\cong}$ & હે \\
\hline & $\begin{array}{l}\bar{N} \\
\text { II } \\
\text { ত্ত }\end{array}$ & $\begin{array}{l}0 \\
.00 \\
.0\end{array}$ & $\vec{\infty}$ & $\stackrel{0}{\cong}$ & \begin{tabular}{l}
0 \\
0 \\
\hdashline \\
\hdashline
\end{tabular} & $\stackrel{\partial}{\approx}$ & હે & $\underset{ \pm}{\stackrel{+}{ \pm}}$ & 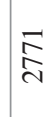 & $\overrightarrow{0}$ & के & 导 & $\stackrel{ }{m}$ & $\begin{array}{l}\vec{\infty} \\
\stackrel{\sim}{\sim}\end{array}$ & $\bar{\alpha}$ & $\underset{\sigma}{=}$ & ڤ્ & 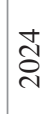 \\
\hline & $\begin{array}{l}0 \\
\text { vI } \\
\text { 엥 }\end{array}$ & $\begin{array}{l}0 \\
0 \\
0 \\
0 \\
0\end{array}$ & $\bar{\nabla}$ & $\begin{array}{l}8 \\
\infty \\
0\end{array}$ & $\stackrel{\infty}{I}$ & $\underline{\tilde{6}}$ & $\frac{2}{n}$ & $\underset{\infty}{\infty}$ & $\underset{N}{\stackrel{N}{N}}$ & 足 & t্ర & ป̃ & $\stackrel{\searrow}{\unrhd}$ & $\bar{m}$ & స్ర & $\frac{\Delta}{m}$ & 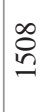 & $\stackrel{\Sigma}{\stackrel{\Sigma}{\Sigma}}$ \\
\hline & $\underset{\nwarrow}{\longleftarrow}$ & & $\stackrel{\varrho}{\Xi}$ & $\stackrel{2}{2}$ & 20 & F & $\stackrel{\partial}{=}$ & 总 & $\frac{\infty}{\grave{ล}}$ & $\stackrel{\infty}{\infty}$ & $\stackrel{\infty}{\alpha}$ & 客 & $\overline{\mathbf{n}}$ & ๙ે & $\hat{\mathrm{D}}$ & $\stackrel{\bar{\beth}}{\beth}$ & $\stackrel{\tilde{\vartheta}}{ \pm}$ & $\overline{\widetilde{6}}$ \\
\hline 䓂 & 至 & & 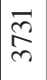 & $\frac{\hat{\sigma}}{m}$ & $\overrightarrow{\tilde{n}}$ & ڤે & $\frac{\infty}{n}$ & $\begin{array}{l}\infty \\
\infty \\
\infty \\
m\end{array}$ & ฬे & $\cong$ & $\stackrel{\Xi}{\stackrel{n}{v}}$ & 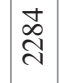 & 岱 & 艺 & $\stackrel{\mathcal{I}}{m}$ & $\begin{array}{l}\infty \\
\approx \\
\approx\end{array}$ & $\frac{n}{o}$ & $\vec{\sim}$ \\
\hline 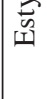 & 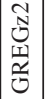 & & त్ర & $\begin{array}{l}+ \\
\infty \\
\end{array}$ & 吕 & $\begin{array}{l}\mathbb{1} \\
\infty \\
\infty\end{array}$ & $\stackrel{0}{\bar{\sim}}$ & 志 & $\stackrel{\infty}{\stackrel{\infty}{\sigma}}$ & $\stackrel{\varrho}{\propto}$ & 仝 & 告 & $\frac{0}{\pi}$ & 命 & 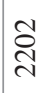 & $\frac{\infty}{\pi}$ & 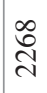 & $\frac{\infty}{\widehat{\lambda}}$ \\
\hline & 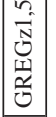 & & $\begin{array}{l}\stackrel{2}{a} \\
\sqrt{3}\end{array}$ & $\begin{array}{l}\infty \\
\sim \\
\sim \\
\sim\end{array}$ & ปิ & 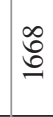 & å & $\stackrel{\swarrow}{\stackrel{\infty}{=}}$ & 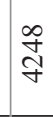 & $\stackrel{+}{\infty}$ & $\stackrel{\substack{n \\
\infty}}{\infty}$ & $\tilde{\kappa}$ & $\overrightarrow{\hat{n}}$ & ర్రి & $\begin{array}{l}\infty \\
\stackrel{\infty}{\sim}\end{array}$ & さ & $\overrightarrow{\widetilde{d}}$ & 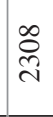 \\
\hline & $\begin{array}{l}\vec{N} \\
\text { II } \\
\text { 엉 }\end{array}$ & $\overrightarrow{\mathrm{\omega}}$ & 帝 & 突 & 号 & $\overline{\widetilde{\sigma}}$ & రి & $\stackrel{\infty}{I}$ & $\underset{\mathcal{H}}{\stackrel{F}{\sim}}$ & ڤ్ & 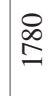 & $\overline{\widehat{ઠ}}$ & 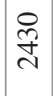 & ঠి & $\stackrel{ }{\stackrel{2}{v}}$ & 宅 & $\hat{\Omega}$ & $\begin{array}{l}\stackrel{0}{0} \\
\text { స్ }\end{array}$ \\
\hline & 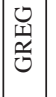 & 2 & $\begin{array}{l}\text { \& } \\
\text { లె } \\
\text { in }\end{array}$ & 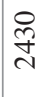 & ळे & $\begin{array}{l}0 \\
0 \\
\infty \\
-1\end{array}$ & $\widehat{\widetilde{\delta}}$ & 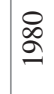 & ชิ & 贞 & $\begin{array}{l}m \\
\stackrel{0}{n}\end{array}$ & $\underset{\sim}{\mathbb{d}}$ & $\stackrel{n}{\stackrel{n}{d}}$ & $\hat{\tilde{n}}$ & $\stackrel{\infty}{\stackrel{0}{\sim}}$ & $\begin{array}{l}\stackrel{\infty}{2} \\
\stackrel{2}{n}\end{array}$ & 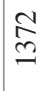 & $\frac{\infty}{\sim}$ \\
\hline & 案 & & 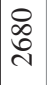 & 윽 & ঠి & ळे & $\stackrel{\infty}{\stackrel{\infty}{\beth}}$ & ટ્ત & $\bar{\sigma}$ & 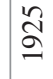 & $\mathscr{\infty}_{0}^{\infty}$ & 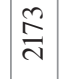 & $\frac{m}{n}$ & ふָ & $\frac{n}{\pi}$ & $\begin{array}{l}\mathbb{J} \\
\text { } \\
\text { (2) }\end{array}$ & ర్ & $\stackrel{\text { I }}{\sim}$ \\
\hline & 匀 & & 宇 & 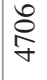 & స్ & त̂ & $\frac{\vec{\sigma}}{\mathrm{m}}$ & ț & $\begin{array}{l} \pm \\
\infty \\
i n\end{array}$ & $\frac{\partial}{m}$ & $\frac{\stackrel{D}{\mathcal{N}}}{m}$ & 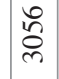 & $\overrightarrow{\bar{r}}$ & $\underset{\infty}{ \pm}$ & $\frac{\infty}{\stackrel{g}{f}}$ & స̃ & $\underset{⿱}{\stackrel{+}{f}}$ & సे \\
\hline & 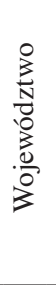 & & 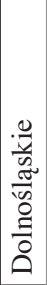 & 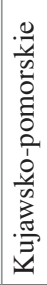 & 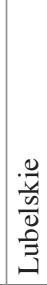 & 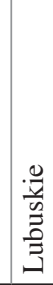 & 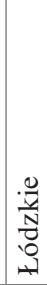 & 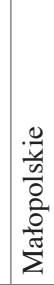 & 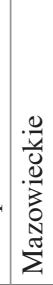 & $\begin{array}{l}\frac{0}{v} \\
\frac{0}{a} \\
0 \\
0 \\
0\end{array}$ & 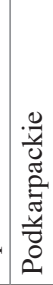 & 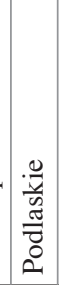 & 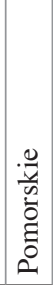 & $\begin{array}{l}\frac{g}{v} \\
\frac{\vec{w}}{v s}\end{array}$ & 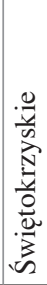 & 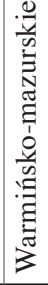 & 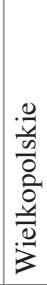 & 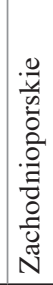 \\
\hline
\end{tabular}




\begin{tabular}{|c|c|c|c|c|c|c|c|c|c|c|c|c|c|c|c|c|c|c|}
\hline & $\begin{array}{l}\mathcal{N} \\
0 \\
T \\
\mathbb{N} \\
\mathbb{U}\end{array}$ & & $\begin{array}{l}\infty \\
\infty \\
\infty\end{array}$ & $\underset{\infty}{\stackrel{D}{0}}$ & $\tilde{\overbrace{}}$ & $\begin{array}{l}8 \\
\stackrel{0}{0} \\
\end{array}$ & $\begin{array}{l}\hat{\sigma} \\
\infty \\
=\end{array}$ & $\stackrel{\mathcal{J}}{\stackrel{\sim}{\sim}}$ & $\begin{array}{l}8 \\
\text { : } \\
0\end{array}$ & $\begin{array}{l}\vec{D} \\
\infty \\
\sim\end{array}$ & 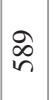 & $\stackrel{\infty}{\infty}$ & 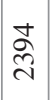 & ڤે & $\stackrel{2}{\infty}$ & $\underset{\stackrel{\mathbb{J}}{\sim}}{\stackrel{\sim}{\sim}}$ & 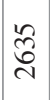 & $\begin{array}{l}\infty \\
\infty \\
\infty\end{array}$ \\
\hline & 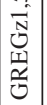 & & ঃి & $\underset{\mathfrak{g}}{\stackrel{g}{c}}$ & $\overrightarrow{\widetilde{d}}$ & $\begin{array}{l}0 \\
\stackrel{4}{2} \\
\text { an }\end{array}$ & $\begin{array}{l}\infty \\
\infty \\
\stackrel{\infty}{=}\end{array}$ & $\begin{array}{l}\stackrel{D}{n} \\
\stackrel{n}{v}\end{array}$ & ָั & $\begin{array}{l}0 \\
\infty \\
\infty \\
\sim\end{array}$ & $\begin{array}{l}\infty \\
\infty \\
i n\end{array}$ & $\begin{array}{l}\infty \\
\vdots \\
\vdots\end{array}$ & 点 & $\begin{array}{l}\hat{2} \\
\hat{2}\end{array}$ & $\stackrel{゚}{2}$ & $\underset{\stackrel{\overbrace{}}{+}}{+}$ & $\begin{array}{l}\hat{2} \\
\stackrel{2}{2}\end{array}$ & లై \\
\hline & 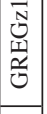 & 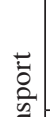 & $\underset{\sim}{\stackrel{a}{d}}$ & $\begin{array}{l}\stackrel{\infty}{\sim} \\
\stackrel{\infty}{*}\end{array}$ & $\begin{array}{c}\infty \\
\stackrel{\overbrace{}}{\sim} \\
\tilde{N}\end{array}$ & $\begin{array}{l}8 \\
\check{n} \\
\end{array}$ & $\underset{I}{\stackrel{I}{I}}$ & $\underset{\infty}{\infty}$ & ণ & $\begin{array}{l}0 \\
\infty \\
\infty \\
\sim\end{array}$ & $\widehat{\widehat{\sigma}}$ & $\begin{array}{l}\infty \\
\vdots \\
\vdots \\
-\end{array}$ & 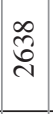 & 命 & 苍 & $\begin{array}{l}\tilde{\infty} \\
\tilde{N}\end{array}$ & $\begin{array}{l}\infty \\
\infty \\
\infty \\
\sim\end{array}$ & $\frac{\curvearrowright}{\sigma}$ \\
\hline & 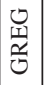 & 覀 & ڤ̊ & 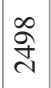 & ஓి & 站 & $\bar{\Xi}$ & $\overrightarrow{\widetilde{N}}$ & ga & $\frac{0}{2}$ & $\ddot{\mho}$ & $\overrightarrow{\grave{D}}$ & $\begin{array}{l}\overrightarrow{\widetilde{d}} \\
\text { त }\end{array}$ & 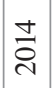 & 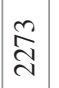 & $\stackrel{\mathcal{I}}{\sim}$ & $\begin{array}{l}\tilde{N} \\
\infty \\
\infty \\
\sim\end{array}$ & त̂ \\
\hline & 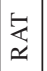 & & 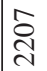 & ஓి & হิ) & 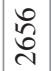 & 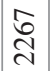 & 垈 & 守 & $\frac{\infty}{\grave{2}}$ & त్రి & $\begin{array}{l}\infty \\
\cdots \\
\approx \\
\end{array}$ & 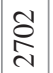 & $\underset{\stackrel{N}{\sim}}{\mathrm{N}}$ & $\begin{array}{l}\infty \\
\infty \\
\stackrel{\infty}{\infty}\end{array}$ & 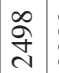 & \& & 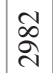 \\
\hline 节 & $\underline{I}$ & & $\underset{\text { J }}{\stackrel{\text { f }}{f}}$ & 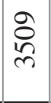 & $\stackrel{\infty}{\underset{f}{f}}$ & 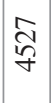 & $\frac{\mathfrak{c}}{\stackrel{f}{\gamma}}$ & 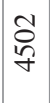 & 垔 & $\frac{n}{\mathfrak{d}}$ & \begin{tabular}{l|}
$\infty$ \\
0 \\
$\infty$ \\
$\infty$
\end{tabular} & $\begin{array}{l}n \\
0 \\
0 \\
n\end{array}$ & $\begin{array}{l}\vec{\sigma} \\
\stackrel{\infty}{+}\end{array}$ & 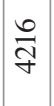 & 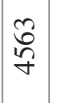 & $\begin{array}{l}\infty \\
\infty \\
\infty\end{array}$ & 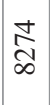 & $\frac{n}{\delta}$ \\
\hline 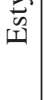 & $\begin{array}{l}\mathbb{N} \\
0 \\
\mathbb{N} \\
\mathbb{N} \\
0\end{array}$ & & $\underset{⿱}{\stackrel{+}{f}}$ & $\frac{\mathfrak{q}}{q}$ & $\begin{array}{l}\hat{\infty} \\
\stackrel{y}{y} \\
\text { on }\end{array}$ & 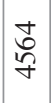 & 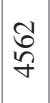 & \begin{tabular}{l}
$\infty$ \\
$\infty$ \\
\multirow{N}{N}{}
\end{tabular} & I & $\frac{\bar{\sigma}}{n}$ & ঐิ & 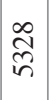 & $\hat{\tilde{y}}$ & 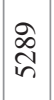 & $\begin{array}{l}\mathfrak{y} \\
\infty \\
m\end{array}$ & $\overrightarrow{\hat{b}}$ & $\begin{array}{l}\stackrel{R}{r} \\
\text { r }\end{array}$ & స్త్ర \\
\hline & $\begin{array}{l}\bar{N} \\
0 \\
\mathbb{1} \\
0 \\
0\end{array}$ & & 斿 & ঙิ & $\stackrel{2}{q}$ & $\begin{array}{c}\hat{n} \\
\stackrel{q}{q}\end{array}$ & 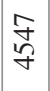 & $\begin{array}{l}\infty \\
\infty \\
\tilde{n}\end{array}$ & $\underset{\infty}{\stackrel{n}{N}}$ & $\begin{array}{l}2 \\
0 \\
\text { in }\end{array}$ & $\underset{\vec{\infty}}{\vec{\sigma}}$ & $\begin{array}{l}\tilde{\approx} \\
\tilde{n}\end{array}$ & $\begin{array}{l}\text { 导 } \\
\text { 守 }\end{array}$ & $\begin{array}{l}\mathscr{8} \\
\stackrel{8}{+}\end{array}$ & $\begin{array}{l}\stackrel{\infty}{\infty} \\
\text { m }\end{array}$ & $\frac{n}{n}$ & 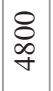 & $\underset{\widetilde{\sigma}}{\tilde{6}}$ \\
\hline & $\mid$\begin{tabular}{|l}
$\vec{N}$ \\
$\mathbb{1}$ \\
$\mathbb{0}$ \\
0
\end{tabular} & $\bar{\nabla}$ & 훙 & $\underset{m}{\vec{m}}$ & 孛 & $\underset{\mathcal{T}}{\mathcal{T}}$ & 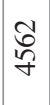 & $\begin{array}{l}0 \\
i n \\
i n\end{array}$ & $\bar{n}$ & 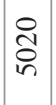 & $\begin{array}{l}n \\
\infty \\
o \\
o \\
+\end{array}$ & $\begin{array}{l}\vec{D} \\
\text { n. }\end{array}$ & 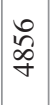 & 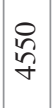 & 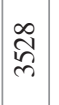 & $\begin{array}{l}n \\
\infty \\
\infty \\
n\end{array}$ & $\begin{array}{l}\stackrel{8}{0} \\
\stackrel{+}{q}\end{array}$ & $\overrightarrow{\widetilde{\sigma}}$ \\
\hline & 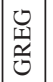 & II & ஓे & $\stackrel{\widetilde{T}}{\mathcal{\gamma}}$ & $\frac{+}{\stackrel{a}{\sigma}}$ & $\begin{array}{l}\infty \\
2 \\
6 \\
ల\end{array}$ & 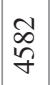 & so & 学 & $\begin{array}{l}\infty \\
2 \\
\infty \\
+\infty\end{array}$ & òे & $\begin{array}{l}\infty \\
\frac{m}{n} \\
i n\end{array}$ & $\begin{array}{l}\infty \\
\infty \\
i \\
\text { in }\end{array}$ & 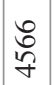 & § & $\begin{array}{l}\hat{b} \\
\infty \\
m\end{array}$ & 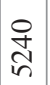 & $\vec{n}$ \\
\hline & $\underset{\nwarrow}{\mathbb{2}}$ & & $\stackrel{\text { }}{\text { ‡ิ }}$ & 竎 & 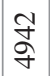 & 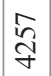 & $\begin{array}{l}\mathscr{2} \\
\infty \\
\dot{+} \\
+\end{array}$ & 옹 & $\stackrel{n}{2}$ & $\begin{array}{l}0 \\
2 \\
i \\
i n\end{array}$ & 寽 & $\hat{\tilde{N}}$ & $\begin{array}{l}\tilde{2} \\
\tilde{n} \\
\text {. }\end{array}$ & \begin{tabular}{l}
$\stackrel{2}{\hat{\gamma}}$ \\
\multirow{\gamma}{*}{}
\end{tabular} & $\frac{m}{2}$ & $\begin{array}{l}+ \\
\infty \\
\infty \\
m\end{array}$ & $\begin{array}{c}\tilde{D} \\
\infty \\
\sim \\
\sim\end{array}$ & $\begin{array}{l}\mathscr{6} \\
6 \\
6\end{array}$ \\
\hline & 吉 & & 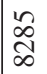 & $\begin{array}{l}\overrightarrow{0} \\
\infty\end{array}$ & $\frac{0}{a}$ & $\stackrel{\circ}{\stackrel{\infty}{\curvearrowright}}$ & 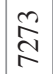 & $\underset{⿱}{\stackrel{O}{J}}$ & $\begin{array}{l}\hat{\hat{\delta}} \\
\infty\end{array}$ & gे & ลิ & 竎 & $\begin{array}{c}\hat{ल} \\
\hat{\infty}\end{array}$ & 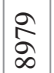 & ஓே & $\begin{array}{l}\text { స్ర } \\
\text { ర్t }\end{array}$ & $\frac{n}{a}$ & బે \\
\hline & $\begin{array}{l}0 \\
0 \\
0 \\
0 \\
0 \\
0 \\
0 \\
0 \\
3\end{array}$ & & 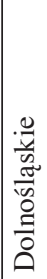 & 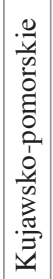 & \begin{tabular}{|l} 
\\
\\
$\frac{9}{2}$ \\
$\frac{0}{0}$ \\
$\frac{0}{0}$ \\
$\frac{0}{3}$ \\
\end{tabular} & 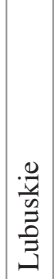 & 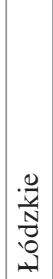 & 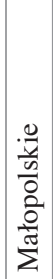 & 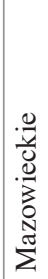 & 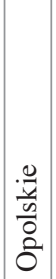 & 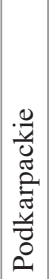 & 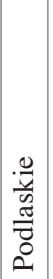 & 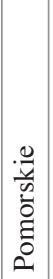 & 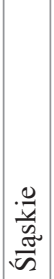 & . & 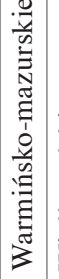 & 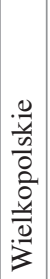 & 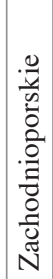 \\
\hline
\end{tabular}




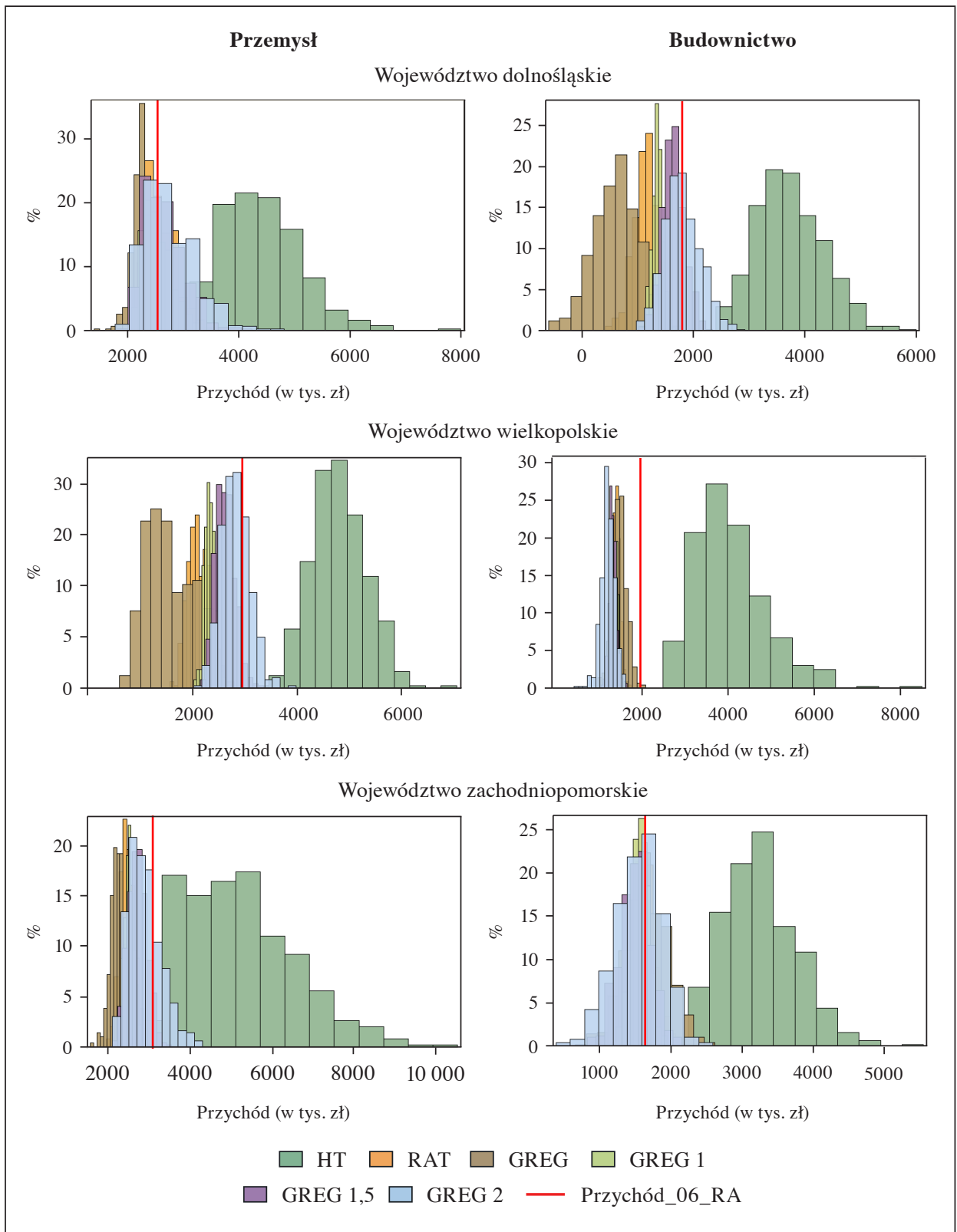

Rys. 10. Rozkład szacunków dla wybranych województw - przemysł i budownictwo Źródło: opracowanie własne na podstawie danych pochodzących z badania DG-1 oraz rejestrów administracyjnych. 


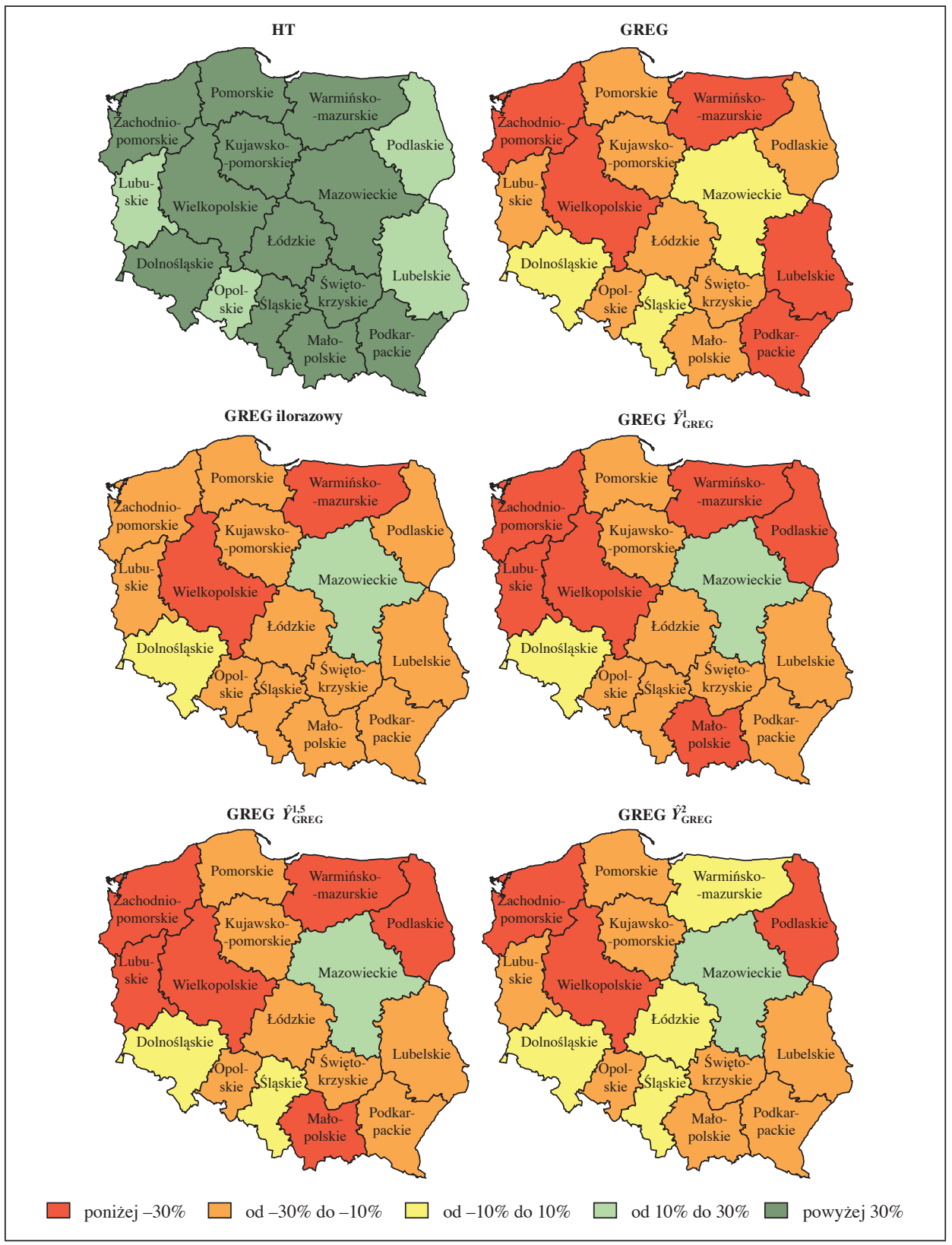

Rys. 11. Porównanie względnego obciążenia szacunku przychodów przedsiębiorstw na podstawie estymatorów HT oraz typu GREG w województwach - przemysł

Źródło: opracowanie własne na podstawie danych pochodzących z badania DG-1 oraz rejestrów administracyjnych. 
Na rys. 10 przedstawiono histogramy prezentujące rozkłady szacunków otrzymanych na podstawie badanych estymatorów metodą bootstrap dla sekcji „przemysł” i „budownictwo” dla wybranych województw. Estymatory GREG, w których wykorzystano zmienne pomocnicze pochodzące z rejestrów, charakteryzują się zdecydowanie mniejszym obciążeniem szacunków. W ich przypadku widoczna jest wyraźna koncentracja rozkładów wokół wartości referencyjnej oznaczonej czerwoną linią.

W celu przestrzennego zobrazowania rozbieżności pomiędzy oszacowaniami i wartościami rzeczywistymi sporządzono wykresy mapowe ukazujące nasilenie obciążenia w przekroju wszystkich województw (por. rys. 11). Wyniki przeprowadzonego badania wskazują, że w zdecydowanej większości domen oceny estymatorów otrzymane na podstawie estymatora HT są przeszacowane w porównaniu z wartościami zawartymi w rejestrach administracyjnych. Największe rozbieżności widoczne są w przypadku estymatora HT. Zastosowanie estymacji typu GREG wpłynęło na zmniejszenie obciążenia, jednak zakres poprawy był zróżnicowany. Na różnice miał wpływ nie tylko rodzaj estymatora GREG, ale również badana domena.

\section{Wnioski}

Otrzymane wyniki badań pozwalają na sformułowanie następujących wniosków:

- włączenie do szacunku zmiennych pomocniczych w ramach estymacji GREG wpłynęło na znaczną poprawę precyzji w porównaniu z estymacją HT,

- w przypadku zastosowania metody nieklasycznej większą poprawę obserwujemy dla domen charakteryzujących się znacznym zróżnicowaniem i silną asymetrią zarówno jeśli chodzi o precyzję, jak i dokładność szacunku,

- w badaniu biorą udział jedynie jednostki, dla których zmienna ' $z$ ' jest różna od 0 ; oznacza to, że w badaniu za zmienną ' $z$ ' można przyjąć jedynie cechę, która nie przyjmuje wartości zerowych,

- stopień poprawy precyzji estymacji w przypadku estymatorów uwzględniających transformację uzależniony jest od odpowiedniego doboru wartości parametru $\gamma$. Znaczną poprawę można osiągnąć, dobierając do danej domeny odpowiedni model. Postępowanie takie powoduje jednak, że stosowanie przedstawionych w artykule zmodyfikowanych estymatorów GREG w przypadku dużej liczby małych domen jest czasochłonne i znacznie utrudnione.

\section{Literatura}

Bracha C. [2004], Estymacja danych z badania aktywności ekonomicznej ludności na poziomie powiatów dla lat 1995-2002, GUS, Warszawa. 
Chambers R., Chandra H., Salvati N., Tzavidis N. [2014], Outlier Robust Small Area Estimation, ,Journal of the Royal Statistical Society: Series B (Statistical Methodology)”, vol. 76, no 1, https://doi.org/10.1111/rssb.12019.

Chambers R.L., Falvey H., Hedlin D., Kokic P. [2001], Does the Model Matter for GREG Estimation? A Business Survey Example, ,Journal of Official Statistics”, vol. 17, nr 4.

Clark R.G., Kokic P., Smith P.A. [2017], A Comparison of Two Robust Estimation Methods for Business Surveys, „International Statistical Review”, vol. 85, nr 2, https:// doi.org/10.1111/insr.12177.

Dehnel G. [2014], Winsorization Methods in Polish Business Survey, „Statistics in Transition - New Series", vol. 15, nr 1.

Dehnel G. [2016], M-estimators in Business Statistics, „Statistics in Transition - New Series", vol. 17, $\mathrm{nr} 4$.

Dehnel G. [2017], GREG Estimation with Reciprocal Transformation for a Polish Business Survey [w:] Proceedings of the 11th Professor Aleksander Zelias International Conference on Modelling and Forecasting of Socio-Economic Phenomena, eds M. Papież, S. Śmiech, Foundation of the Cracow University of Economics, Cracow.

Lehtonen R., Särndal C.E., Veijanen A. [2016], Generalized Regression and Model-calibration Estimation for Domains: Accuracy Comparison, https://www.researchgate. net/publication/228665672_Generalized_regression_and_model-calibration_estimation_for_domains_Accuracy_comparison (data dostępu: 17.12.2017).

Ludność. Stan i struktura demograficzno-społeczna. Narodowy Spis Powszechny Ludności i Mieszkań 2011 [2013], GUS, Warszawa.

Rao J.N.K., Molina I. [2015], Small Area Estimation, 2nd ed., Wiley Series in Survey Methodology, Wiley, Hoboken, New Jersey.

Särdnal C.E., Swensson B., Wretman J. [1992], Model Assisted Survey Sampling, Springer Verlag, New York.

Wykorzystanie danych administracyjnych w badaniu: Ocena bieżqcej działalności gospodarczej przedsiębiorstw [2016], GUS, Warszawa.

\section{Model Selection and the GREG Estimator Bias in a Small Business Survey}

(Abstract)

Estimation for a very skewed population containing extreme values is problematic, especially at a low level of aggregation. Traditional direct estimation methods do not provide satisfactory results. The growing demand for detailed information and the wider possibility of using data from administration registers has increased the importance of recognising more sophisticated estimation methods. Generalised Regression (GREG) estimation is an example of one such type. The paper examines the importance of the model chosen in GREG estimation in dealing with highly variable and outlier-prone populations. The model-assisted GREG estimator is applied to a real business survey. Lagged variables from administrative registers were used as the auxiliary variables. The variable of interest - mean revenue of small companies - was estimated for provinces cross-classified by categories of economic activity.

Keywords: GREG, business statistics, model-assisted estimation, outliers. 